\title{
Correction to: Psychological well-being in people with multiple sclerosis: a descriptive review of the effects obtained with mindfulness interventions
}

\author{
Marcella Di Cara ${ }^{1}$. Denise Grezzo ${ }^{1}$. Rosanna Palmeri ${ }^{1}$. Viviana Lo Buono ${ }^{1}$ - Emanuele Cartella ${ }^{1}$ Katia Micchia ${ }^{1}$. \\ Caterina Formica ${ }^{1}$. Carmela Rifici ${ }^{1}$. Edoardo Sessa ${ }^{1}$. Giangaetano D'Aleo ${ }^{1}$ - Giuseppa Maresca ${ }^{1}$. Placido Bramanti ${ }^{1}$. \\ Francesco Corallo ${ }^{1}$
}

Published online: 16 December 2021

(c) The Author(s) 2021

Correction to: Neurological Sciences (2021)

https://doi.org/10.1007/s10072-021-05686-1

Originally, the article was published online with inverted author names. This is now corrected here.

The original article has been corrected.

Open Access This article is licensed under a Creative Commons Attribution 4.0 International License, which permits use, sharing, adaptation, distribution and reproduction in any medium or format, as long as you give appropriate credit to the original author(s) and the source, provide a link to the Creative Commons licence, and indicate if changes were made. The images or other third party material in this article are included in the article's Creative Commons licence, unless indicated otherwise in a credit line to the material. If material is not included in the article's Creative Commons licence and your intended use is not permitted by statutory regulation or exceeds the permitted use, you will need to obtain permission directly from the copyright holder. To view a copy of this licence, visit http://creativecommons.org/licenses/by/4.0/.

Publisher's note Springer Nature remains neutral with regard to jurisdictional claims in published maps and institutional affiliations.

The original article can be found online at https://doi.org/10.1007/ s10072-021-05686-1

Viviana Lo Buono

viv.lobuono@gmail.com

1 IRCCS Centro Neurolesi "Bonino-Pulejo”, S.S, 113 Via,

Palermo, C.da Casazza, 98124 Messina, Italy 